\title{
Analysis of Patients with Central Nervous System Infection at Our Clinic: Five-year Results
}

\author{
Kliniğimizde Yatan Santral Sinir Sistemi Enfeksiyonu Tanıı Hastaların Analizi: Beş Yıllık Sonuçlar
}

\author{
(1) Şafak Özer BALIN, (1) Ayşe SAĞMAK TARTAR, (1) Kutbeddin DEMIRDAĞ, (1) Ayhan AKBULUT \\ Fırat University Faculty of Medicine Hospital, Department of Infectious Diseases and Clinical Microbiology, Elazığ, Turkey
}

\section{Abstract}

Introduction: This study aimed to determine the epidemiological data, clinical and laboratory findings, morbidity, and mortality of patients with central nervous system infection (CNSI).

Materials and Methods: Patients who were followed-up in our clinic with a diagnosis of CNSI between 2013 and 2018 were reviewed retrospectively. Results: A total of 55 patients with a mean age of $46 \pm 19$ (19-90) years were included in the study; $58.1 \%$ of the patients were male. Acute bacterial meningitis was observed in $54.5 \%$ of the patients, aseptic meningitis in $23.6 \%$, tuberculous meningitis in $5.5 \%$, and meningoencephalitis in $16.4 \%$ (88.8\% of these patients were defined as highly probable encephalitis). The most common symptom was fever. The prevalence of the classical triad (fever, neck stiffness, and change in mental status) in patients with acute bacterial meningitis was 36.6\%. Streptococcus pneumoniae was the most common causative agent identified in cerebrospinal fluid (CSF) and blood culture. Cerebrospinal fluid acid-fast bacillus positivity in tuberculous meningitis and CSF herpes simplex virus polymerase chain reaction-1 positivity in meningoencephalitis was 33.3\%. The complication rate was 18.1\%. The only mortality was in one patient with acute bacterial meningitis.

Conclusion: According to the results of our study, fever, change in mental status, headache, and signs of meningeal irritation are essential in predicting CNSI. However, these indicators rarely presented altogether in our patients. Therefore, patients who do not exhibit the classical triad but are suspected of CNSI should undergo lumbar puncture for CSF analysis and antimicrobial treatment should be started as soon as possible. The low mortality rate among our patients once again demonstrates the importance of this approach.

Keywords: Acyclovir, ceftriaxone, epidemiology, encephalitis, vancomycin

\section{$\ddot{\mathrm{O} z}$}

Giriş: Bu çalışmanın amacı hastanemizde santral sinir sistemi enfeksiyonu (SSSE) tanısıyla takip edilen olguların epidemiyolojik verileri, klinik ve laboratuvar bulguları ile morbidite ve mortalite oranlarını belirlemektir.

Gereç ve Yöntem: Kliniğimizde 2013-2018 tarihleri arasında SSSE tanısıyla izlenen hastalar retrospektif olarak incelenmiştir.

Bulgular: Çalışmaya yaş ortalaması 46ะ19 (19-90) yıl olan toplam 55 olgu dahil edildi. Hastaların \%58,1'i erkekti. Tüm olgular değerlendirildiğinde, akut bakteriyel menenjit \%54,5, aseptik menenjit \%23,6, tüberküloz menenjiti \%5,5 ve meningoensefalit \%16,4 (bu hastaların \%88,8'i yüksek olasılıklı ensefalit olarak tanımlandı) oranında gözlendi. Hastalarımızda en sık görülen belirti ve bulgu ateşti. Akut bakteriyel menenjit hastalarında klasik triad, (ateş, ense sertliği ve bilinç değişikliği birlikteliği) oranı \%36,6 olarak saptandı. Beyin omurilik sıvısı (BOS) ve kan kültüründe en sık üreyen etken Streptococcus pneumoniae idi. Tüberküloz menenjitte BOS aside dirençli basil pozitifliği oranı ve meningoensefalitte BOS herpes simpleks virüs-1 polimeraz zincir reaksiyonu testi pozitifliği oranı \%33,3 olarak bulundu. Olgularda görülen komplikasyon oranı \%18,1 iken; sadece akut bakteriyel menenjit tanısı ile takip edilen bir hasta kaybedildi.

Sonuç: Çalışmamızdan elde edilen verilere göre ateş, bilinç değişikliği, baş ağrısı ve meningeal irritasyon bulguları SSSE'yi öngörmede önemlidir. Ancak hastalarımızda bu belirteçlerin birlikteliğinin sık olmadığı saptanmıştır. Bu sebeple klasik triadı karşılamayan ancak SSSE şüphesi olan hastalarda lomber ponksiyon yapılarak BOS incelenmeli ve en kısa sürede antimikrobiyal tedaviye başlanmalıdır. Nitekim hastalarımızın mortalite oranının düşük olması, bu yaklaşımın önemini bir kez daha ortaya koymaktadır.

Anahtar Kelimeler: Asiklovir, seftriakson, epidemiyoloji, ensefalit, vankomisin

Cite this article as: Balın ŞÖ, Sağmak Tartar A, Demirdağ K, Akbulut A. Analysis of Patients with Central Nervous System Infection at Our Clinic: Five-year Results. Mediterr J Infect Microb Antimicrob. 2019;8:13.

Address for Correspondence/Yazışma Adresi: Şafak Özer Balın MD, Fırat University Faculty of Medicine Hospital, Department of Infectious Diseases and Clinical

Microbiology, Elazığ, Turkey

Phone: +90 5059174187 E-mail: safakozerbalin@hotmail.com 0RCID: orcid.org/0000-0002-3722-4660

Received/Geliş Tarihi: 23.11.2018 Accepted/Kabul Tarihi: 23.04.2019

oCopyright 2019 by the Infectious Diseases and Clinical Microbiology Specialty Society of Turkey

Mediterranean Journal of Infection, Microbes and Antimicrobials published by Galenos Yayınevi. 


\section{Introduction}

Central nervous system infections (CNSI) still cause significant mortality and morbidity around the world. Many pathogens may cause CNSI. Today, early diagnosis and treatment increase the likelihood of a favorable outcome ${ }^{[1]}$. Central nervous system infections have broad clinical spectrum, ranging from meningitis, encephalitis, and encephalomyelitis to brain abscess, subdural empyema, epidural abscess, neuritis, and intracranial phlebitis ${ }^{[2]}$. Bacteria and viruses are the most common etiologic factors in acute meningitis ${ }^{[3]}$. Most cases of community-acquired acute bacterial meningitis are caused by Streptococcus pneumoniae, Neisseria meningitidis, Haemophilus influenzae, Listeria monocytogenes, and group B streptococci ${ }^{[4]}$. Enteroviruses, herpesviruses, adenovirus, rhinovirus, human immunodeficiency virus, influenza, mumps, lymphocytic choriomeningitis virus, and arboviruses are the most common agents in the etiology of acute viral meningitis and meningoencephalitis ${ }^{[5]}$. Cerebrospinal fluid (CSF) examination is essential for diagnosis. Determining cell count, measuring glucose and protein levels, and Gram staining to detect microorganisms in CSF facilitate treatment planning. Other diagnostic methods include CSF culture, serological tests, imaging methods, and agent-specific molecular and biological tests ${ }^{[1,6]}$.

The etiological distribution of meningitis/meningoencephalitis varies depending on age, geographical differences, season, susceptibility of the population to certain agents, genetic background, socioeconomic conditions, and local endemic factors ${ }^{[2,7]}$.

The aim of this study was to identify morbidity and mortality rates based on the epidemiologic data and clinical and laboratory findings of patients treated for community-acquired CNSI in a tertiary care hospital.

\section{Materials and Methods}

The study included patients diagnosed with CNSI who were followed in the Infectious Diseases and Clinical Microbiology Department of our hospital between January 2013 and October 2018. The patients' epidemiologic data, clinical findings, and laboratory results were obtained retrospectively.

Diagnosis of CNSI was made based on patient history, physical examination findings, CSF examination, and radiological imaging techniques such as computed tomography (CT) and magnetic resonance $(M R)^{[1,6]}$. History of headache, high fever, nausea/vomiting, change in mental status, and convulsion or examination findings of high fever, change in mental status, signs of meningeal irritation, and focal neurological signs were evaluated in favor of CNSI. The classical triad rate (fever, nuchal rigidity, and altered mental status) in acute bacterial meningitis was found by analysing the copresence of these symptoms ${ }^{[8]}$. In all patients, CSF analyses included cell count and cell type analysis, protein and glucose level measurement, Gram staining, and bacteriological culture (CSF and blood culture). BACTEC system was used for blood culture. Vitek 2 (Biomerieux, USA) automated systems were used for identification of strains. All patients with aseptic meningitis, meningoencephalitis, and tuberculous meningitis were performed tuberculosis culture and CSF polymerase chain reaction (PCR) analysis for herpes simplex virus (HSV) and tuberculosis. These tests were not performed in patients with prediagnosis of acute bacterial meningitis.

Lumbar puncture was performed on all patients in our study with signs and symptoms of CNSI, and diagnosis was based on the results of CSF biochemical evaluation, Gram staining, and culture. All patients underwent tomography prior to lumbar puncture.

\section{Diagnostic Criteria}

In patients with clinical signs and symptoms, diagnosis was based on CSF analysis, microbiological identification, and radiological imaging ${ }^{[3,7,9,10]}$. Accordingly, CSF biochemical parameters confirmed the diagnosis in patients suspected of CNSI based on clinical presentation. The diagnosis was confirmed with molecular methods and microbiological and radiological findings. The diagnostic criteria used with the patients are given in Table 1.

Acute bacterial meningitis was diagnosed in patients with consistent signs and symptoms (e.g., headache, fever, neck stiffness, and Kernig's or Brudzinski's sign) in the presence of CSF leukocyte count $>1000 / \mathrm{mm}^{3}$ (polymorphonuclear leukocyte $>80 \%$ ), CSF protein concentration of $100-500 \mathrm{mg} / \mathrm{dl}$, CSF glucose concentration $<40 \mathrm{mg} / \mathrm{dl}$, CSF/blood glucose ratio $\leq 0.4$, and/or positive CSF/blood culture or detection of infectious bacteria in the microscopic examination of stained samples ${ }^{[3]}$.

Aseptic meningitis was diagnosed in the presence of CSF leukocyte count of $50-1000 / \mathrm{mm}^{3}$ (mononuclear cell dominant), CSF protein concentration $<200 \mathrm{mg} / \mathrm{dl}$, CSF glucose concentration $>45 \mathrm{mg} / \mathrm{dl}$, and/or detection of viral genetic material in the CSF using molecular methods such as $\mathrm{PCR}^{[3]}$.

Tuberculous meningitis was diagnosed in the presence of CSF leukocyte count of $50-300 / \mathrm{mm}^{3}$ (mononuclear cell dominant), CSF protein concentration $<45 \mathrm{mg} / \mathrm{dl}$, isolation of Mycobacterium tuberculosis in culture and/or detection of $M$. tuberculosis genetic material in CSF using molecular methods and/or detection of basilar arachnoiditis and/or tuberculoma in cranial MR imaging (MRI), and demonstration of response to antituberculosis treatment ${ }^{[10]}$. 
Table 1. Diagnostic criteria ${ }^{[3,9]}$

\begin{tabular}{l|l|l|l|l}
\hline & Acute purulent meningitis & Aseptic meningitis & Tuberculous meningitis & Meningoencephalitis \\
\hline White blood cell count & $>1000 / \mathrm{mm}^{3}$ & $50-1000 / \mathrm{mm}^{3}$ & $50-300 / \mathrm{mm}^{3}$ & $<1000 / \mathrm{mm}^{3}$ \\
\hline Cell type & PMNL & MNL & MNL & $\mathrm{MNL}$ \\
\hline Protein, $\mathrm{mg} / \mathrm{dl}$ & $100-500$ & $<200$ & $50-300$ & $15-50$ \\
\hline Glucose, mg/dl & $<40$ & $>45$ & $<45$ & $>45$ \\
\hline CSF/blood glucose & $\leq 0.4$ & $>0.6$ & $<0.4$ & $\geq 0.6$ \\
\hline Positive Gram staining & + & - & - & - \\
\hline AFB staining & - & - & + & - \\
\hline Positive culture & + & - & + & - \\
\hline TB PCR & - & - & + & - \\
\hline HSV PCR & - & + & - & + \\
\hline Pathologic involvement in cranial MRI & - & + & + & + \\
\hline Abnormal EEG findings & - & - & - & + \\
\hline
\end{tabular}

CSF: Cerebrospinal fluid, PMNL: Polymorphonuclear leukocyte, MNL: Mononuclear leukocyte, AFB: Acid-fast bacillus, TB: Tuberculosis, HSV: Herpes simplex virus,

EEG: Electroencephalography, MRI: Magnetic resonance imaging, PCR: Polymerase chain reaction

Viral meningoencephalitis was diagnosed in patients with symptoms such as headache, fever, and nuchal rigidity as well as new-onset neurological symptoms and varying degrees of altered mental status, in the presence of CSF leukocyte count $<1000 / \mathrm{mm}^{3}$ (lymphocyte dominant), CSF protein concentration within normal range or slightly elevated, CSF blood glucose $\geq 0.6$, detection of HSV-DNA in CSF using PCR, detection of signs suggesting encephalitis in electroencephalography and/ or neuroimaging analyses ${ }^{[3,7]}$. Diagnosis of encephalitis was supported by the diagnostic criteria defined by Venkatesan et al. ${ }^{[11]}$.

Based on these diagnostic criteria, the patients were categorized into four groups: acute bacterial meningitis, aseptic meningitis, tuberculous meningitis, and meningoencephalitis ${ }^{[2]}$. Patients over 18 years old who met the diagnostic criteria were included in the study. Patients who did not undergo lumbar puncture, had suspected hospital-associated CNSI, had incomplete medical records, and/or did not meet the diagnostic criteria were excluded.

\section{Statistical Analysis}

SPSS version 22 package software (SPSS IBM, Armonk, NY, USA) used for data analysis. Kolmogorov-Smirnov and Shapiro-Wilk tests were used to test whether the variables fit to normal distribution. Continuous variables with normal distribution were presented as mean \pm standard deviation, while variables with non-normal distribution were presented as median (minimummaximum). Categorical variables were presented as frequency and percentage. Mann-Whitney $\mathrm{U}$ test was used in comparisons of continuous variables. Qualitative data were compared using the Chi-square test. A p value $<0.05$ was considered statistically significant.
The study was conducted in accordance with the principles of the Declaration of Helsinki and was approved by the Firat University Institutional Review Board (approval date and no: 07/11/2018, 18-02).

\section{Results}

Fifty-five patients with a mean age of $46 \pm 19$ (minimum 19-maximum 90) years were included in this study. Of these patients, 58.1\% ( $n=32)$ were male. According to the specified diagnostic criteria, $54.5 \%(n=30)$ of the patients had acute bacterial meningitis, 23.6\% ( $n=13)$ had aseptic meningitis, $5.5 \%(n=3)$ had tuberculous meningitis, and $16.4 \%(n=9)$ had meningoencephalitis. All of the encephalitis patients showed altered mental status and fever, $33.3 \%(n=3)$ had new-onset focal neurological symptoms, $55.5 \%(n=5)$ had parenchymal involvement suggesting encephalitis in radiological imaging, and $33.3 \%(n=3)$ had seizures. Based on the diagnostic criteria established by Venkatesan et al. ${ }^{[11]}, 88.8 \%(n=8)$ of these patients had probable (major $+\geq 3$ minor) and 11.1\% ( $n=1)$ had possible (major +2 minor) encephalitis. Mean age was 52.5 (19-90) years in the acute bacterial meningitis group, 42 (20-83) years in the aseptic meningitis group, $42(38-49)$ years in the tuberculous meningitis group, and 38 (25-70) years in the meningoencephalitis group. There was no significant age difference between the groups $(p=0.753)$. The demographic, clinical, and laboratory parameters of the patients are shown in Table 2.

The main complaints at presentation were fever (81.8\%), change in mental status $(65.5 \%)$, headache $(60 \%)$, nausea/vomiting $(34.5 \%)$, and seizure $(27.3 \%)$, while the most common physical examination findings were fever (85.4\%), nuchal rigidity (54.5\%), Kernig's sign (10.9\%), and Brudzinski's sign (12.7\%). Coexistence 
of three meningeal irritation symptoms was detected in only three (5.4\%) patients, two in bacterial meningitis and one in viral meningitis. Twenty-three patients (41.8\%) had only a single symptom of meningeal irritation. Comparison of signs and symptoms between the groups revealed headache as the only significant difference. Headache was significantly more common in bacterial meningitis and aseptic meningitis than in meningoencephalitis ( $p=0.015$ and $p=0.04$, respectively). The prevalence of the classical triad among patients with acute bacterial meningitis was $36.6 \%(n=11)$. Two patients $(7 \%)$ with acute bacterial meningitis exhibited extensive skin rash. Herpes labialis accompanied 13\% $(n=4)$ of the patients with acute bacterial meningitis and $15 \%(n=2)$ of the patients with aseptic meningitis.
Laboratory results indicated white blood cell count was 12,200/ $\mathrm{mm}^{3}\left(4,800-33,270 / \mathrm{mm}^{3}\right)$, neutrophil count was $10,410 / \mathrm{mm}^{3}$ $\left(2,740-13,230 / \mathrm{mm}^{3}\right)$, C-reactive protein (CRP) concentration was $46 \mathrm{mg} / \mathrm{l}$ (3-221 $\mathrm{mg} / \mathrm{l})$, and erythrocyte sedimentation rate (ESR) was $37 \mathrm{~mm} / \mathrm{h}(1-98 \mathrm{~mm} / \mathrm{h})$. Acute bacterial meningitis patients had higher leukocyte and CRP values than the patients with aseptic meningitis and meningoencephalitis $(p=0.037$ and $p=0.017$, respectively). Erythrocyte sedimentation rate was significantly higher in acute bacterial meningitis than meningoencephalitis and tuberculous meningitis $(p=0.047$ and $p=0.039$, respectively).

In microbiological analyses of CSF samples from patients with acute bacterial meningitis, the agent was determined by means of Gram staining in $20 \%(n=6)$ of the patients and

Table 2. Demographic, clinical, and laboratory data of the patients

\begin{tabular}{|c|c|c|c|c|c|}
\hline & $\begin{array}{l}\text { Acute bacterial meningitis } \\
30(54.5 \%)\end{array}$ & $\begin{array}{l}\text { Aseptic meningitis } \\
13(23.6 \%)\end{array}$ & $\begin{array}{l}\text { Meningoencephalitis } \\
9(16.4 \%)\end{array}$ & $\begin{array}{l}\text { Tuberculous } \\
\text { meningitis } 3(5.5 \%)\end{array}$ & $\mathbf{p}$ \\
\hline \multicolumn{6}{|c|}{ Demographic characteristics } \\
\hline Age, years (median) & 52.5 & 42 & 38 & 42 & 0.753 \\
\hline Female/male & $11 / 19$ & $8 / 5$ & $2 / 7$ & $2 / 1$ & 0.058 \\
\hline \multicolumn{6}{|l|}{ Symptoms } \\
\hline Fever $\left(>38.3^{\circ} \mathrm{C}\right)$ & $22(73 \%)$ & $12(92 \%)$ & $8(89 \%)$ & $3(100 \%)$ & 0.345 \\
\hline Headache & $21(70 \%)$ & $9(69 \%)$ & $2(22 \%)$ & $1(33 \%)$ & 0.029 \\
\hline Nausea/vomiting & $9(30 \%)$ & $5(38 \%)$ & $4(44 \%)$ & $1(33 \%)$ & 0.864 \\
\hline Changes in mental state & $20(66 \%)$ & $7(53 \%)$ & $7(78 \%)$ & $2(67 \%)$ & 0.711 \\
\hline Seizures & $8(27 \%)$ & $3(23 \%)$ & $3(33 \%)$ & $1(33 \%)$ & 0.953 \\
\hline Loss of balance & $4(13 \%)$ & $1(8 \%)$ & $4(44 \%)$ & - & 0.049 \\
\hline \multicolumn{6}{|c|}{ Physical examination findings } \\
\hline Fever $\left(>37.8^{\circ} \mathrm{C}\right)$ & $24(80 \%)$ & $12(92 \%)$ & $8(89 \%)$ & $3(100 \%)$ & 0.345 \\
\hline Nuchal rigidity & $16(53 \%)$ & $9(69 \%)$ & $4(44 \%)$ & $1(67 \%)$ & 0.124 \\
\hline Kernig's sign & $4(13 \%)$ & $1(8 \%)$ & $1(11 \%)$ & - & 0.11 \\
\hline Brudzinski's sign & $5(16 \%)$ & $1(8 \%)$ & $1(11 \%)$ & - & 0.114 \\
\hline Skin rash & $2(7 \%)$ & - & - & - & \\
\hline Herpes labialis & $4(13 \%)$ & $2(15 \%)$ & - & & 0.745 \\
\hline \multicolumn{6}{|l|}{ Laboratory values (median) } \\
\hline Leukocytes/mm³ & 15,505 & 9,060 & 7,690 & 12,440 & 0.037 \\
\hline Neutrophil/mm ${ }^{3}$ & 14,420 & 7,090 & 6,520 & 9,800 & \\
\hline $\mathrm{CRP}(\mathrm{mg} / \mathrm{l})$ & 128.5 & 10 & 3 & 5 & 0.017 \\
\hline $\mathrm{ESR}(\mathrm{mm} / \mathrm{h})$ & 44.5 & 35 & 20 & 22 & 0.042 \\
\hline \multicolumn{6}{|l|}{ CSF findings (median) } \\
\hline Cell count $/ \mathrm{mm}^{3}$ & 4800 & 180 & 60 & 270 & 0.001 \\
\hline Protein (mg/dl) & 149 & 43 & 54 & 99 & 0.003 \\
\hline Glucose (mg/dl) & 29 & 50 & 52 & 54 & 0.042 \\
\hline CSF glucose/blood glucose & 0.26 & 0.68 & 0.72 & 0.48 & 0.025 \\
\hline \multicolumn{6}{|l|}{ CSF findings, $\mathrm{n}(\%)$} \\
\hline \multicolumn{6}{|l|}{ Cell count $/ \mathrm{mm}^{3}$} \\
\hline $0-100$ & $2(7 \%)$ & $4(31 \%)$ & $6(67 \%)$ & - & 0.029 \\
\hline $101-200$ & $1(3 \%)$ & $5(38 \%)$ & $2(22 \%)$ & $1(33 \%)$ & 0.059 \\
\hline $201-500$ & $4(13 \%)$ & $3(23 \%)$ & $1(11 \%)$ & - & 0.485 \\
\hline $501-1000$ & $9(30 \%)$ & $1(8 \%)$ & - & $2(67 \%)$ & 0.055 \\
\hline$>1001$ & $14(47 \%)$ & - & - & - & \\
\hline \multicolumn{6}{|l|}{ Cell type } \\
\hline PMNL & $28(93 \%)$ & $1(8 \%)$ & $1(11 \%)$ & $3(100 \%)$ & 0.014 \\
\hline MNL & $2(7 \%)$ & $12(92 \%)$ & $8(9 \%)$ & - & 0.012 \\
\hline
\end{tabular}

CRP: C-reactive protein, ESR: Erythrocyte sedimentation rate, CSF: Cerebrospinal fluid, PMNL: Polymorphonuclear leukocytes, MNL: Mononuclear leukocytes 
growth in CSF culture was detected in 16.6\% $(n=5)$ of the patients. Streptococcus pneumoniae was detected in $80 \%$ $(\mathrm{n}=4)$ of the positive cultures and Neisseria meningitidis in $20 \%(n=1)$. S. pneumoniae was detected in the blood culture of $10 \%(n=3)$ of the patients. In tuberculous meningitis, CSF acid-fast bacillus (AFB) staining was positive in $33.3 \%$ of the patients $(n=1)$. However, no growth was detected in any of the patients' CSF cultures. HSVDNA was was positive in three (33\%) of the meningoencephalitis cases. Viral cell culture could not be performed using the CSF from our patients. The diagnosis of two patients $(22.2 \%)$ with persistent clinical suspicion of encephalitis was made based on follow-up lumbar puncture. Encephalitis diagnosis was confirmed by initial lumbar puncture findings in other cases.

Pathology was detected on radiological imaging in $55.5 \%(n=5)$ of the encephalitis patients, $100 \%(n=3)$ of the tuberculous meningitis patients, and $30 \%(n=9)$ of the acute bacterial meningitis patients. These findings included temporal/ frontotemporal involvement and hemorrhage in the encephalitic region in encephalitis patients; tuberculoma, hydrocephalus, and basilar arachnoiditis in tuberculous meningitis patients; and peripheral contrast enhancement, focal cerebritis, and ventriculitis in acute bacterial meningitis patients. There were no pathological signs in viral meningitis. Electroencephalography was performed only on two patients diagnosed with viral encephalitis and revealed no signs of pathology.

The overall prevalence of complications was $18.1 \%(n=10)$, with the highest complication rate $(60 \%, n=6)$ in meningoencephalitis patients. Complications were brain abscess $(40 \%, n=4)$, subdural empyema $(40 \%, n=4)$, and hydrocephalus $(20 \%, n=2)$.

Two of the encephalitis patients in our study had hemiplegia; one of the two tuberculous meningitis patients had hearing loss in the right ear and the other patient had ptosis, resulting in a complication rate of $7.2 \%(n=4)$. No sequelae were observed in the bacterial and viral meningitis patients.

Eighty percent $(n=44)$ of the patients received combination antibiotic therapy. Treatment of patients with tuberculous meningitis involved administration of quadruple antituberculosis therapy and steroids for the first two months, followed by rifampicin and isoniazid therapy for a total duration of one year. Ceftriaxone + vancomycin or ceftriaxone + vancomycin + ampicillin combination therapies were administered to $19(63.3 \%)$ of the bacterial meningitis patients, while 11 patients (36.6\%) received ceftriaxone monotherapy. Nine (30\%) of the patients with bacterial meningitis were treated with dexamethasone at a dose of $0.6 \mathrm{mg} / \mathrm{kg} /$ day for four days. All of the patients with aseptic meningitis/meningoencephalitis were administered acyclovir + ceftriaxone therapy.
Of all the patients, only one died (1.8\%). This patient was a 55 -year-old man who presented with high fever, changes in mental status, seizures, nausea, and vomiting. Findings of meningeal irritation included nuchal rigidity and Brudzinski's sign. He had no comorbidities and was diagnosed with acute bacterial meningitis. He died four hours after hospital admission.

\section{Discussion}

Central nervous system infections are among the conditions that cause high morbidity and mortality ${ }^{[3]}$. CNSI comprise a broad clinical spectrum, from meningitis to encephalitis, brain abscess to encephalomyelitis. However, among all of these clinical presentations, the most common are bacterial and viral meningitis ${ }^{[1]}$. Demiroğlu et al. ${ }^{[12]}$ reported that $56.9 \%$ of patients diagnosed with CNSI had acute bacterial meningitis, 23.5\% had viral meningitis, and $19.6 \%$ had tuberculous meningitis. Köse et al. ${ }^{[13]}$ determined that $47.8 \%$ of diagnosed cases were acute bacterial meningitis and $10.8 \%$ were tuberculous meningitis. In another study, the prevalence of meningoencephalitis was found to be $28.7 \% \%^{[14]}$. Compared to the literature data, the rate of tuberculous meningitis was lower in our study. This may be attributable to the relatively smaller number of patients included in our study sample.

In another study performed in Turkey, the mean age of meningoencephalitis patients was 43.2 years ${ }^{[14]}$. In a study by Pişkin et al. ${ }^{[15]}$ including 244 patients, $45.5 \%$ were female and $54.5 \%$ were male. The mean age was 39.8 years overall, 41.4 years in acute bacterial meningitis patients, 36.8 years in viral meningitis patients, and 37.5 years in tuberculous meningitis patients. Our results were consistent with the literature. As reported in many other studies, males were predominant among our CNSI patients $(58.1 \%)^{[4,12,15]}$.

The most common presenting symptoms in patients with CNSI are fever, headache, nausea/vomiting, changes in mental status, and signs of meningeal irritation ${ }^{[3]}$. Studies have shown that the frequency of headache and fever at admission were 89$96 \%$ and $86-94 \%$, respectively, in acute bacterial meningitis patients ${ }^{[16,17]}$. Kahraman et al. ${ }^{[18]}$ reported that the most common complaints at admission were headache (86\%), fever (83\%), nausea/vomiting (60\%), changes in mental status (57\%), and somnolence (45\%). The patients in our study exhibited signs and symptoms consistent with those in the literature. However, adults with bacterial meningitis may not always show classical clinical symptoms. Therefore, suspicion of bacterial meningitis should not based on the presence of classical triad alone ${ }^{[8]}$. The frequency of the classical triad was reported as $66 \%$ by Hussein and Shafran ${ }^{[19]}, 44 \%$ by van de Beek et al. ${ }^{[20]}$, and $59 \%$ by Weisfelt et al. ${ }^{[21]}$. This rate was $36.6 \%$ among the acute bacterial 
meningitis patients in our study, which is much lower than previous reports. This indicates that the classical triad is not adequately sensitive for the diagnosis of meningitis.

When evaluated according to the diagnostic criteria of Venkatesan et al. ${ }^{[11]}$, all encephalitis patients had altered mental status as well as fever, new-onset focal neurological symptoms, seizure, and radiological findings of parenchymal involvement suggestive of encephalitis.

Çelik et al. ${ }^{[16]}$ found that blood leukocyte levels were significantly higher in acute bacterial meningitis than aseptic and tuberculous meningitis. Demiroğlu et al. ${ }^{[12]}$ reported high CRP and ESR values in acute bacterial meningitis patients: $94.5 \pm 77.0 \mathrm{mg} / \mathrm{l}$ and $50.5 \pm 30.7 \mathrm{~mm} / \mathrm{h}$, respectively. Similar to other studies, we observed high leukocyte count, CRP, and ESR values in the acute bacterial meningitis patients in our study.

The rate of bacterial detection in CSF Gram staining has been reported to range between $60-90 \%$ and the culture positivity rate as $70 \%$ in acute bacterial meningitis ${ }^{[22]}$. Pişkin et al. ${ }^{[15]}$ reported only a $17.3 \%$ culture positivity rate in patients with bacterial meningitis. In another study, the rate of bacterial detection in CSF Gram staining was reported as $36.7 \%$, and the rate of bacterial isolation from culture as $38.6 \%{ }^{[4]}$. The rate of bacteriological identification in the presented study was low. In our study, the most frequently isolated bacterium in acute bacterial meningitis cases was $S$. pneumoniae, which is consistent with many previous studies in the literature ${ }^{[4,15,16]}$. Hoşoğlu et al. ${ }^{[23]}$ reported AFB positivity in $15.8 \%$ and culture positivity in $11.9 \%$ of CSF samples. In another study, CSF analysis revealed no AFB positivity, while 20\% of the CSF cultures were positive $^{[12]}$. In our study, only one of the three (33.3\%) CSF samples were AFB-positive but mycobacterial cultures were negative. Herpes simplex encephalitis is the main cause of sporadic fatal encephalitis ${ }^{[24]}$. In studies performed in Turkey, the rate of HSV-associated CNSI is $9.7-19 \% \%^{[25,26]}$. This rate was found to be $1 \%$ in another study by Soylar et al. ${ }^{[27]}$ and $16.6 \%$ in a study by Demiroğlu et al. ${ }^{[12]}$ We determined a higher rate in our study, which may be explained by our repeating HSV PCR with follow-up lumbar puncture in some of the encephalitis cases with ongoing clinical suspicion. This eliminates false negative HSV PCR results from the lumbar punctures performed at admission.

All of the patients in our study underwent tomography before lumbar puncture. Cranial imaging is recommended prior to lumbar puncture in cases of focal neurological deficit or new-onset seizure, severe changes in mental status, and immunocompromised patients ${ }^{[8]}$. From this point of view, it seems that radiological imaging was performed unnecessarily before lumbar puncture in some of our patients. This can be attributed to the classic approach used for most patients who present to the emergency department with altered mental status and seizure. Cranial CT and MRI are usually not helpful in the diagnosis of acute bacterial meningitis ${ }^{[3]}$. However, all patients with suspected infectious encephalitis must undergo MRI unless contraindicated since $89 \%$ of patients with HSV have abnormal MRI findings in the temporal lobe ${ }^{[28,29]}$. Taşdelen-FIşgın et al. ${ }^{[14]}$ detected abnormal MRI findings in $44.4 \%$ of patients with viral encephalitis. In tuberculous meningitis, basilar arachnoiditis, infarction, hydrocephalus, or tuberculomas may be observed on $\mathrm{CT}^{[30]}$. Pişkin et al. ${ }^{[15]}$ detected subdural empyema in $3.8 \%$ $(n=5)$, brain abscess in $3 \%(n=4)$, and hydrocephalus in $2.3 \%$ $(n=3)$ of patients with bacterial meningitis. Consistent with similar studies, abnormal radiological findings observed in our study included involvement of the temporal/frontotemporal region and hemorrhage in encephalitic region in encephalitis patients; tuberculoma, hydrocephaly, and basilar arachnoiditis in tuberculous meningitis patients; and peripheral contrast enhancement, focal cerebritis, and ventriculitis in acute bacterial meningitis patients.

CNSI is still associated with severe neurological complications today. Subdural empyema, brain abscess, and hydrocephaly were among the complications reported by Pişkin et al. ${ }^{[15]}$ In a multicenter study by Erdem et al. ${ }^{[31]}$ that included 2583 patients, suppurative intracranial infection was detected in 5.6\% of the patients, with most cases consisting of brain abscess $(n=97)$, epidural abscess $(n=31)$, and subdural empyema $(n=14)$. In our study, brain abscess, subdural empyema, and hydrocephaly were the most common sequalae. Köse et al. ${ }^{[13]}$ reported that $6.5 \%(n=3)$ of patients recovered with sequelae. Demiroğlu et al. ${ }^{[12]}$ observed memory disorders and behavioral changes as sequelae in encephalitis patients, and neurogenic bladder and left homonymous hemianopsia in tuberculous meningitis patients. Erdem et al. ${ }^{[31]}$ reported the frequency of sequelae to be $18.5 \%$, with the most common sequelae being motor deficit $(5 \%)$, cranial nerve involvement $(3.6 \%)$, cognitive disorder $(2.7 \%)$, persistent headache $(1.5 \%)$, and epilepsy $(1 \%)$. Sequelae observed in our study were hemiplegia, hearing loss, and ptosis.

When choosing empirical antibiotherapy, the patient's age and comorbidities, pharmacokinetic and pharmacodynamic of the antibiotic, expected pathogens, and local antibiotic resistance patterns should be considered ${ }^{[3]}$. The treatments used in the present study are similar with the literature ${ }^{[8,15,32]}$.

Rapid initiation of treatment is critical to reduce mortality in CNSI. Taşdelen-Fışgın et al. ${ }^{[14]}$ reported a mortality rate of $8.5 \%$, while Diktaş et al. ${ }^{[33]}$ found this rate to be $3.6 \%$. In our study, only one patient diagnosed with acute bacterial meningitis $(1.8 \%)$ died.

Herein, the data of patients diagnosed and treated for CNSI in our center were obtained. However, the study has several 
limitations. These include the limited number of patients, low rate of microbiological identification, lack of PCR analysis for bacterial agents, not following patients for post-discharge survival, not using cell culture methods, lack of data on patient comorbidities or conditions that may cause immunosuppression, and lack of vaccination data.

\section{Conclusion}

CNSI are associated with significant morbidity and mortality. Early diagnosis and treatment are extremely important. Although fever, nuchal rigidity, and altered mental state are important predictors of CNSI, these symptoms were rarely found together in our patients. Therefore, in patients who do not exhibit the classic triad but are suspected of having CNSI, lumbar puncture should be performed unless contraindicated for CSF analysis and antimicrobial therapy should be initiated as soon as possible. The low mortality rate among our patients once again demonstrates the importance of this approach.

\section{Ethics}

Ethics Committee Approval: The study was conducted in accordance with the principles of the Declaration of Helsinki and was approved by the Firat University Institutional Review Board (approval date and no: 07/11/2018, 18-02).

Informed Consent: Retrospective study.

Peer-review: Externally and internally peer-reviewed.

\section{Authorship Contributions}

Medical Practices:Ş.Ö.B., A.A., Concept:Ş.Ö.B., A.A., Design:Ş.Ö.B., A.A., Data Collection or Processing: S..Ö.B., A.S.T., Analysis or Interpretation: Ş.Ö.B., K.D., A.A., Literature Search: Ş.Ö.B., A.S.T., Writing: Ş.Ö.B., A.S.T.

Conflict of Interest: No conflict of interest was declared by the authors.

Financial Disclosure: The authors declared that this study received no financial support.

\section{References}

1. Marra CM, Whitley RJ, Scheld WM. Approach to the patient with central nervous system infection. In: Scheld WM, Whitley RJ, Marra CM (eds). Infections of the Central Nervous System. $3^{\text {th }}$ ed. Philadelphia: Lippincott Williams\&t Wilkins, 2004:1-4.

2. Tülek N, Tanyel E. Santral sinir sistemi enfeksiyonlarına genel bakış. In: Topçu AW, Söyletir G, Doğanay M (eds). Infeksiyon Hastalıkları ve Mikrobiyolojisi Cilt 1, 3. Baskı. İstanbul: Nobel Tıp Kitapevleri, 2008:137588.

3. Tunkel AR, Van de beek $D$, Scheld WM. Acute meningitis. In: Mandell GL, Bennett JE, Dolin R (eds). Mandell, Douglas, and Bennett's Principles and Practice of Infectious Diseases. $8^{\text {th }}$ ed. Philadelphia, PA: Churchill Livingstone Elsevier, 2015:1097-137.
4. Arda B, Sipahi OR, Atalay S, Ulusoy S. Pooled analysis of 2408 cases of acute adult purulent meningitis from Turkey. Med Princ Pract. 2008;17:76-9.

5. Calleri G, Libanore V, Corcione $\mathrm{S}$, De Rosa FG, Caramello P. A retrospective study of viral central nervous system infections: relationship amongst aetiology, clinical course and outcome. Infection. 2017;45:227-31.

6. Graham TP. Myth: Cerebrospinal fluid analysis can differentiate bacterial meningitis from aseptic meningitis. Can J Emerg Med. 2003;5:348-9.

7. Arısoy ES. In: Topçu AW, Söyletir G, Doğanay M (eds). Enfeksiyon Hastalıkları ve Mikrobiyolojisi. $3^{\text {th }}$ ed. İstanbul: Nobel Tıp Bookstore, 2008:422-30.

8. Van de Beek D, Cabellos C, Dzupova O, Esposito S, Klein M, Kloek AT, Leib SL, Mourvillier B, Ostergaard C, Pagliano P, Pfister HW, Read RC, Sipahi OR, Brouwer MC; ESCMID Study Group for Infections of the Brain (ESGIB). ESCMID guideline: diagnosis and treatment of acute bacterial meningitis. Clin Microbiol Infect. 2016;22(Suppl 3):37-62.

9. Tunkel AR. Approach to the Patient with Central Nervous System Infection. In: Mandell GL, Bennett JE, Dolin R (eds). Mandell, Douglas, and Bennett's Principles and Practice of Infectious Diseases. $8^{\text {th }}$ ed. Philadelphia, PA: Churchill Livingstone Elsevier, 2015:1091-6.

10. Bennett JE. Chronic meningitis. In: Mandell GL, Bennett JE, Dolin R (eds). Mandell, Douglas, and Bennett's Principles and Practice of Infectious Diseases. $7^{\text {th }}$ ed. Philadelphia, PA: Churchill Livingstone Elsevier, 2010:123741.

11. Venkatesan A, Tunkel AR, Bloch KC, Lauring AS, Sejvar J, Bitnun A, Stahl JP, Mailles A, Drebot M, Rupprecht CE, Yoder J, Cope JR, Wilson MR, Whitley RJ, Sullivan J, Granerod J, Jones C, Eastwood K, Ward KN, Durrheim DN Solbrig MV, Guo-Dong L, Glaser CA; International Encephalitis Consortium. Case definitions, diagnostic algorithms, and priorities in encephalitis: consensus statement of the international encephalitis consortium. Clin Infect Dis. 2013;57:114-28.

12. Demiroğlu $Y Z$, Turunç $T$, Alışkan $H$, Çolakoğlu Ş, Erdoğan AF, Arslan H. Community Acquired Meningitis/Meningoencephalitis: Retrospective Evaluation of Five Years. Turkiye Klinikleri J Med Sci. 2010;30:218-26.

13. Köse Ş, Göl B, Atalay S, Akkoçlu G. Evaluation of Five-Year Meningitis Cases in Tepecik Training and Research Hospital. Klimik Derg. 2013;26:54-7.

14. Taşdelen-Fışgın N, Tanyel E, Zıvaloğlu M, Tülek N. Central nervous system infections: experience of a tertiary referral academic centre. İnfeksiyon Dergisi E. 2007;21:169-74.

15. Pişkin N, Yalçın A, Aydemir H, Gürbüz Y, Tütüncü E, Türkyılmaz R. Evaluation of 244 Central Nervous System Infection Cases. Flora. 2005;10:119-24.

16. Çelik I, Özden M, Kılıçoğlu A, Demirdağ K, Kılıç SS. Retrospective evaluation of 121 meningitis cases. Klimik Derg. 2003;16:11-4.

17. Buzgan $T$, Karahocagil MK, Irmak $H$, Binici i, Karsen $H$, Akdeniz $H$. Retrospective Evaluation of Two Hundred and Four Bacterial Meningitis Cases. Turkiye Klinikleri J Med Sci. 2010;30:1675-82.

18. Kahraman $\mathrm{H}$, Tunger $\mathrm{A}$, Senol $\mathrm{S}$, Gazi H, Avci M, Ormen B, Turker N, Atalay S, Kose S, Ulusoy S, Tasbakan MI, Sipahi OR, Yamazhan T, Gulay Z, Cavus SA, Cicek C, Pullukcu H. Investigation of Bacterial and Viral Etiology in Community Acquired Central Nervous System Infections with Molecular Methods. Mikrobiyol Bul. 2017;51:277-85.

19. Hussein AS, Shafran SD. Acute Bacterial Meningitis in Adults: A 12-Year Review. Medicine (Baltimore). 2000;79:360-8.

20. Van de Beek D, De Gans J, McIntyre P, Prasad K. Steroids in Adults With Acute Bacterial Meningitis: A Systematic Review. Lancet Infect Dis. 2004;4:139-43.

21. Weisfelt M, De Gans J, van der Poll T, van de Beek D. Pneumococcal Meningitis in Adults: New Approaches to Management and Prevention. Lancet Neurol. 2006;5:332-42.

22. Wispelwey B, Tunkel AR, Scheld WM. Bacterial meningitis in adults. Infect Dis Clin North Am. 1990;4:645-59. 
23. Hoşoğlu S, Geyik MF, Balik I, Aygen B, Erol S, Aygencel SG, Mert A, Saltoğlu N, Dökmetaş I, Felek S, Sünbül M, Irmak H, Aydin K, Ayaz C, Kökoğlu $\mathrm{OF}$, Uçmak $\mathrm{H}$, Satilmiş $\mathrm{S}$. Tuberculous meningitis in adults in Turkey: epidemiology, diagnosis, clinic and laboratory [corrected]. Eur J Epidemiol. 2003;18:337-43.

24. Tyler KL. Herpes simplex virus infections of the central nervous system: Encephalitis and meningitis, including Mollaret's. Herpes. 2004;11(Suppl 2):57-64.

25. Sayiner A, Oktem M, Ergani A, Ergon C, Kurul S, Abacioglu YH. Detection of herpes simplex virus DNA and enterovirus RNA in cerebrospinal fluid using PCR and microplate or strip hybridization assay. Clin Microbiol Infect 2003;9 (Suppl 1):410.

26. Altuglu I, Zeytinoglu A, Sirin H, Yuceyar N, Erensoy S. Comparison of different polymerase chain reaction methods for detection of herpes simplex virus types 1 and 2 encephalitis. Eur J Clin Microbiol Infect Dis. 2006;25:669-71.

27. Soylar M, Altuğlu I, Sertöz R, Aydın D, Akkoyun F, Zeytinoğlu A. Viral agents in patients with central nervous infections admitted to Ege University Hospital. Ege Journal of Medicine. 2014;53:65-70.

28. Tyler KL, Beckham JD. Encephalitis. In: Mandell GL, Bennett JE, Dolin R eds. Mandell, Douglas, and Bennett's Principles and Practice of Infectious Diseases. $8^{\text {th }}$ ed. Philadelphia, PA: Churchill Livingstone Elsevier, 2015:114463.

29. Raschilas F, Wolf M, Delatour F, Chaffaut C, De Broucker T, Chevret S, Lebon $\mathrm{P}$, Canton $\mathrm{P}$, Rozenberg F. Outcome of and prognostic factors for herpes simplex encephalitis in adult patients: results of a multicenter study. Clin Infect Dis. 2002;35:254-60.

30. Ribera E, Martinez-Vazquez JM, Ocana I, Segura RM, Pascual C. Activity of adenosine deaminase in cerebrospinal fluid for the diagnosis and followup of tuberculous meningitis in adults. J Infect Dis. 1987;155:603-7.

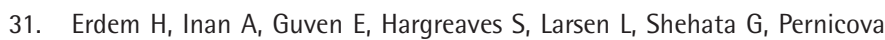
E, Khan E, Bastakova L, Namani S, Harxhi A, Roganovic T, Lakatos B, Uysal S, Sipahi OR, Crisan A, Miftode E, Stebel R, Jegorovic B, Fehér Z, Jekkel C, Pandak N, Moravveji A, Yilmaz H, Khalifa A, Musabak U, Yilmaz S, Jouhar A, Oztoprak N, Argemi X, Baldeyrou M, Bellaud G, Moroti RV, Hasbun R, Salazar L, Tekin R, Canestri A, Čalkić L, Praticò L, Yilmaz-Karadag F, Santos L, Pinto A, Kaptan F, Bossi P, Aron J, Duissenova A, Shopayeva G, Utaganov B, Grgic S, Ersoz G, Wu AKL, Lung KC, Bruzsa A, Radic LB, Kahraman H, Momen-Heravi M, Kulzhanova S, Rigo F, Konkayeva M, Smagulova Z, Tang T, Chan P, Ahmetagic S, Porobic-Jahic H, Moradi F, Kaya S, Cag Y, Bohr A, Artuk C, Celik I, Amsilli M, Gul HC, Cascio A, Lanzafame M, Nassar M. The burden and epidemiology of community-acquired central nervous system infections: a multinational study. Eur J Clin Microbiol Infect Dis. 2017;36:1595-611.

32. Tunkel AR, Glaser CA, Bloch KC, Sejvar JJ, Marra CM, Roos KL, Hartman BJ, Kaplan SL, Scheld WM, Whitley RJ; Infectious Diseases Society of America. The management of encephalitis: clinical practice guidelines by the Infectious Diseases Societyof America. Clin Infect Dis. 2008;47:303-27.

33. Diktaş $H$, Hatipoğlu $M$, Turhan $V$, Acar A, Öncül 0 , Koçak N, Görenek L. Retrospective Evaluation of Cases with the Diagnosis of Acute Bacterial Meningitis Over a 33-Year Period. Flora. 2012;17:161-6. 